\title{
Collective Intelligence and University Entrepreneurial Performance: An Exploratory Study Among Teacher Researchers and Students from Chadian Universities
}

\author{
Victor Mignenan \\ Department of Management, Faculty of Business Sciences and Techniques, University of Moundou, Moundou, Chad
}

Email address:

Victor.mignenan1@uqac.ca

\section{To cite this article:}

Victor Mignenan. Collective Intelligence and University Entrepreneurial Performance: An Exploratory Study Among Teacher Researchers and Students from Chadian Universities. Science Journal of Business and Management. Vol. 9, No. 2, 2021, pp. 103-118.

doi: $10.11648 /$ j.sjbm.20210902.17

Received: May 25, 2021; Accepted: June 9, 2021; Published: June 21, 2021

\begin{abstract}
The research on intellectual capital carried out so far for the academic entrepreneurial development is few but has clearly shown its importance. However, the overall contribution of intellectual capital to the performance of academic entrepreneurial projects of both technologies, social and environmental or university spin-offs remains little studied. Even studies carried out on this subject, often, focus only on a single component and favor, for the most part, the quantitative approach. This posture does not allow us to understand which of the three components of intellectual capital is the best predictor of academic entrepreneurial performance. Thus, the results of these previous studies provide little information on how to increase entrepreneurship by mobilizing intellectual capital. To fill these gray areas and facilitate an understanding of the causal link between intellectual capital and academic entrepreneurial performance, a semi-structured interview of eleven entrepreneurs and a survey of 278 researchers and students from four Chadian universities were conducted. The research process was mixed. We used an approach that focused on both economic/financial entrepreneurship, social entrepreneurship (which is part of the obligations of Chadian universities) and societal/environmental entrepreneurship. During data production, we have put forward the criterion of participation of the actor (researcher-student-practitioner) in the various phases of activities in the process of implementation of entrepreneurship. Our results have shown that human capital $\left(\mathrm{R}^{2}=0.21\right)$ and relational capital $\left(\mathrm{R}^{2}=0.29\right)$ are the best predictors of academic entrepreneurial performance. It is mainly relational capital that contributes mainly $(\mathrm{b}=31 \%$ ) academic entrepreneurial performance. These results are explained by the fact that human capital and relational capital are deployed for the purposes of creativity, contact, creation of business networks, etc., while structural capital plays an essential role in the credibility and influence of universities. Finally, it is the combination of the three components of intellectual capital that plays a decisive role $\left(\mathrm{R}^{2}=0.85\right)$ in achieving academic entrepreneurial performance. Thus, universities are invited to revitalize their network of actors, to promote collaborative research, to advocate the agile approach and to enrich their human capital so that it fulfills its mission as an open innovation subject, without neglecting their capital structure for its undeniable support role.
\end{abstract}

Keywords: Management, Intellectual Capital, Entrepreneurship, Performance, University

\section{Introduction}

The university community attaches real privilege to entrepreneurship (i) as a field of scientific investigation and (ii) as a training-action field. Literature [1-3] reports that many academic educational institutions combine theory and practice, from ecosystems dedicated to entrepreneurial practices. For example, universities are seen as carriers of the entrepreneurial approach [4] Although it can take many facets, entrepreneurial activity is essential to improve the influence of any university, especially the social dimension. Through the growth of innovation, the university community values science through practice. Similarly, the culture of entrepreneurial orientation is a true managerial style of some academic institutions. Therefore, without entrepreneurship, the competitive advantage of the productive sector would be impossible [5] This perspective makes the entrepreneurial approach attractive, which is an engine of economic growth. 
However, despite its importance, university entrepreneurship is not very visible, but is not as infallible [6, 7]. Indeed, explicitly available entrepreneurship opportunities are little explored or, worse, ignored by some academic communities. Many factors are said to be at the root of this phenomenon: (i) higher education policy (ii) research and innovation strategies, and (iii) intellectual capital [6, 8]. Of these, intellectual capital management is arguably the least well-explored factor [9] However, several works [2, 10] reveal that within any organization, there is intellectual capital to fertilize entrepreneurship. Extensive research [11, 12] conducted in this field demonstrate that the structure of intellectual capital varies considerably throughout the process of implementing entrepreneurship. In the context of university entrepreneurship, the components of intellectual capital mobilized are more significant, compared to the entrepreneurship carried by the practitioner.

Beyond the above, the work [13-16] conducted so far are devoted, mostly to a single component of intellectual capital to assess entrepreneurial performance. Similarly, most research [9, $11,17,18]$ are either quantitative or qualitative. Research carried out in this perspective in the Chadian context is almost non-existent. The originality of this research lies in the combination of the three components of intellectual capital (human capital, structural capital, and relational capital) to understand academic entrepreneurial performance. Thus, and article aims to answer the following question: what are the components of intellectual capital that have a strong explanatory power over academic entrepreneurial performance?

This research is hybrid in nature and characterized by a qualitative and quantitative trajectory. To produce the qualitative data, eleven semi-structured interviews, with entrepreneurs (researchers and students) from four Chadian universities, were conducted and analyzed in depth. Quantitative data is generated from 178 entrepreneurs made up of researchers and students who have been actively involved in the process of setting up university entrepreneurship. This article is a continuation of the previous publication of our doctoral thesis on a similar topic. It is structured in three points. The first point deals with the theoretical context that leads to the development of a conceptual model. The second point describes the methodological pathway deployed. The third point presents the results, the discussion, and the implications.

\section{Putting in Theoretical Context}

Studies on the management of intellectual capital are based, for the most part, on resource theory [19] Those that address entrepreneurship or business creation, regularly mobilize the contingency perspective, relational dynamics, etc. As part of this research, we are part of the current of resource thoughts to inform the discussion and the implications. However, in the rest of this sequence, it will be specified the theoretical elements defining university entrepreneurship and intellectual capital as well as the role of universities in the constitution of said intellectual capital.

\subsection{State of Knowledge}

According to several authors $[1,4]$ university entrepreneurship is the transformation of scientific or technical knowledge into practical solutions that carry socio-economic or environmental values. While entrepreneurial performance is the result or simply the amount of business creation projects executed in time and space. The characteristics of university entrepreneurship are mainly the signing of agreements or agreements to enhance innovation, technology transfer, or the development of a business model, etc. University entrepreneurship can be carried by a researcher or a team of researchers from faculties/departments who create new activities (swarming, startups, incubators/accelerators). It is in this context that some authors $[20,21]$ identified (i) technological entrepreneurship (ii) social entrepreneurship and (iii) environmental entrepreneurship.

Indeed, technological entrepreneurship involves using the results of scientific and technical research by researchers and students to suggest new and effective solutions to society's problems [22, 23]. According to some authors [20, 24, 25] technological entrepreneurship is a co-production activity of interdisciplinary researchers who have been concerned about a common problem and vision. Example: a startup of biogas for household use implemented by students in the city of N'Djamena (Chad). The process of evolution of technological entrepreneurship emphasizes the combined efforts that link the scientific potential of the university with the creation of business activities. In any case, most technology entrepreneurship projects are characterized by the interactions between science, technology, innovation, and the business ecosystem.

Second, social entrepreneurship is of interest to several researchers [26, 27]. The major element that characterizes it is the emphasis on social benefits. It is real that social value is being put forward for stakeholders. However, the mission of social entrepreneurship remains the satisfaction of social needs, the contribution of researchers and students to society, etc. For example a student housing co-operative; Garage Solitaire, created by mechanical engineering students at the University of Mongo (Chad); Carrefour food innovation company (CIA) created by students of Commercial Techniques at the University of Moundou (Chad). In any case, from a definitional point of view, social entrepreneurship is a much less consensual concept because it is similar to the collaborative economy, the social economy, and the community economy, etc. Therefore some researchers [27-29] argue that the goal of business creation is to redefine societal issues in terms of business opportunities. This is how universities have an implicit obligation to promote socio-economic development. To this end, the university community, through its intellectual capital, is a fertile breeding ground for entrepreneurial development. From this perspective, the challenge of enriching intellectual capital to increase social innovation is an obligation.

Finally, environmental, and societal entrepreneurship is transforming research results into a sustainable societal initiative. For some authors [30] this is the execution of a 
viable project that reconciles societal viability with the general interest. Example: the Sudan Reforestation Society in Chad, created by the network of university teacher researchers in the Sudanese area. Such entrepreneurship is focused on combating environmental degradation, climate change, social equity, etc. [30]. For other researchers, environmental entrepreneurship differs from the traditional path of business creation. The results of two fairly recent studies $[27,30]$ reveal that the entrepreneurial environmental boom is driven by the frequent interaction between the university entrepreneur (researcher/doctoral fellow) and the community. Therefore, successful exchanges between researchers and society are a better trajectory to intensify environmental innovation.

In the context of this study, university entrepreneurship is seen as swarming. More specifically, it is a process by which a new organization that embodies economic, social, or environmental values is created for the benefit of society from the results of scientific or technical research conducted by a researcher, a group of researchers.

However, performance and entrepreneurial success depend, for the most part, on intellectual capital. However, theater proponents have little agreement on the definitional concept. Several authors equate it with intangible capital. Others see it as an intangible resource. This is the case of Klein and Prusak [31] According to these authors, intellectual capital is a set of intellectual material formalized and structured to be used for the production of assets of great values. This lighting is similar to the Nonaka and Takeuchi model [32] on formalized knowledge, i.e., the creation of organizational knowledge. Similarly, many authors believe that intellectual capital is an "intangible asset," "social capital," "knowledge capital" [12, 20, 21, 33-36]. In this study, we borrow the OECD's definition that intellectual capital is made up of human capital, structural capital, and relational capital.

On the basis of the above, human capital is the organization's inimitable resource, it is on it that the object of growth and notoriety of the university rests [20] It is apprehended in the same way as financial capital and is thus considered a source of wealth and value [37-40] According to these authors, it advances productivity and innovation. In the sense of many authors of the current of resources, the $\mathrm{HC}$, within the organization, can grow, shrink, but also become useless if appropriate actions are not taken (Bottler, Cossette, Fournier, Sabourin, 2013). Despite its importance, there is little consensus on the definition of intellectual capital. Indeed, according to several authors [41] the $\mathrm{HC}$ is a heritage of knowledge to be fruitful and not a subject of production. It attests to the workforce of a person or nation and is the result of an investment in education and continuing education. Rodriguez - Loomis [42] defines human capital as a set of knowledge, skills, skills and attributes that facilitate the creation of personal, economic and social well-being. For Becker (1962), human capital is an individual's resources that determine his level of productivity. In this research, we consider human capital to be, "the set of abilities, knowledge, experience, skill, skills, etc. that each researcher and student at the university possesses, allowing him to be inventive,

\section{creative, productive in his specific field."}

Structural capital, on the other hand, concerns procedures, rules, methods, governance, managerial style, databases that support organizational $[3,43]$. To this end, it is presented as the cultural knowledge that the organization has been able to internalize. The wealth and flexibility of structural capital are likely to foster entrepreneurial innovation in academia or university spin-offs. Moreover, structural capital is considered the undeniable support for human capital. It is the framework by which human capital enriches its knowledge, skills, and skill. The dynamic capacity of structural capital is manifested by authorization to test, tolerance for failures (risks) but above all team learning. Thus, structural capital is the trajectory by which the organization measures and appreciates the development of its intellectual capital. For the purposes of this article, we consider structural capital as the philosophy of the organization, which relates to structures, standards, repositories, methods, models, and databases that serve as a medium in which researchers and students can relate to create, innovate, and undertake.

Finally, relational capital is a dimension of intellectual capital based on the idea that organizations, whether they are companies or universities, are not isolated systems, but rather that they are highly dependent on the relationships they create and maintain in their ecosystem. Thus, this capital includes the value generated by these relationships with all stakeholders, both internal and external $[44,45]$. It is relationships of this nature that add value to the organization, which are considered to constitute the university relational capital. In the same vein, Borges - Filion, reveal that this is knowledge included in the organization's relations with its reference stakeholders. In addition, it is understood as the mass of relational capabilities and the variety of the network of partners of the organization [43] Finally, the nature and scope of relational capital is subservient by stakeholders in the entrepreneurial ecosystem as well as the national innovation system. Because of its external source, it is difficult to codify relational capital. In the context of this research, the capital relationship is the whole knowledge of all the relations that the university has with the business network that can promote the identification, formulation, and implementation of entrepreneurial projects, be they technological, social, or environmental.

In this article, we consider intellectual capital as a combination of three intangible assets that play the decisive roles of productivity, support, and value-bearing interaction and on which competitive advantage and notoriety are built.

Considering the above, it is worth stressing the importance other role of universities in the production of intellectual capital. Indeed, universities develop approaches based, strictly on intellectual capital. The reason for this position is that knowledge is the main product and above all the main resource of these training institutions [46] Universities, in terms of intellectual capital, aim to produce and disseminate knowledge. To achieve this goal, they are making huge investments in the training of human resources, in research but also in innovation projects and, increasingly, in the valuation of intellectual capital. Therefore, regardless of size, university resources and products are seen as essentially intangible assets. 
This is why the literature reports that higher education institutions create and possess countless sources of economic value and intangible assets grouped under the generic name "knowledge" or "intellectual capital" [47].

From the perspective of building intellectual capital, the literature reveals that universities are essential entities for the production, transmission, and dissemination of knowledge. More specifically, they have three fundamental missions, including (i) research and enhancement of its results through collaboration with industries, businesses, society, and NGOs, (ii) teaching and continuing education of researchers and practitioners, and (iii) significant contribution to regional and local development $[46,48]$.

Other contributions indicate that academic institutions are responsible for teaching, research and innovation, but they must provide a variety of services to the community [46, 49]. Entrepreneurial orientation through spin-offs, incubators, etc. is part of the innovation axis that depends mainly on research (fundamental and applied). Promoting university entrepreneurship is based on the transformation of science results into products with commercial (commercialization of innovation) and social values. In addition to scientific knowledge, universities offer infrastructure that promotes the commercialization of innovation and intellectual capacity. They offer training, support, and support services to promote the growth of incubators/accelerators. They also serve as spaces for scientific debates. Finally, through experimentation and publications, they serve as breeding ground for scientific and technical knowledge with industries, communities, NGOs, etc.

\subsection{Contribution of Intellectual Capital to Academic Entrepreneurial Performance}

Studies on the relationship between intellectual capital and entrepreneurial performance are recent. Several authors [9, 12, $18,20,50-54]$ found a positive association between intellectual capital and entrepreneurial innovation within companies. The results of these studies have shown that the combination of the three components of intellectual capital is a real catalyst and innovation accelerator of all kinds of companies $[1,4]$. But no research has been conducted in the context of universities, which are, moreover, the preferred places of intellectual capital for innovation in all senses. Similarly, a recent study by two authors [12] reports that an organization's ability to innovate is explained by the quality of its intellectual assets. Again, these studies are only for businesses. Entrepreneurial innovation remains dependent on the intangible capital of the organization but also on the entrepreneurial ecosystem [23, 27-29, 55-58]. In addition, the results of Yaseen's research [8] also highlighted positive signs of multiple correlations and positive and significant linear regressions between indicators of intellectual capital and the development of technological swarms in academia. Other works on business, from the same perspective, has reported positive and statistically significant relationships between the components of intellectual capital and academic entrepreneurial performance [16, 22, 41]. Serener and his colleagues analyzed the link between intellectual capital and innovation outcomes [21] Its results support the hypothesis that the quality of the organization's intellectual capital is positively and statistically significant in the development of innovation projects. However, the author notes that the degree of effect varies significantly from one component to another. However, Yaseen and his colleagues have observed the emergence of variables (structural capital) of intellectual capital negatively correlated with swarming [8] But these studies are not about universities.

Specifically, human capital (HC) is a lever for transforming scientific and technical knowledge into relevant entrepreneurship projects to address societal issues [16] It is seen as an object of growth, a subject of value creation and competitiveness of any organization. This is why several authors $[12,34]$ have shown that companies that perform in entrepreneurial innovation are those that implement better practices in mobilizing human resources. Other authors report that companies that have developed resources based mainly on knowledge are performing in entrepreneurial innovation [59, 60]. It is in the same vision that two works report that the strategic positioning of the company in a competitive environment would be explained by the quality of its intangible resources [61-63]. For some studies [18, 20] these practices focus on investments in education training but also the promotion of organizational agility. For this reason, recent research suggests that universities have an interest in acquiring more of the higher quality intellectual capital, which will enable them to increase their entrepreneurial performance $[9,17,18]$.

Secondly, structural capital (SC), by its standards, referential, field of maneuvers, conveys the company's philosophy and makes its implementation credible. Such capital, according to some authors, offers a framework of scientific, technical and procedural expression that aims to improve innovation performance [17] This assumption is supported by the results of two studies $[13,52]$. According to these results, the SC is one of the predictors of technological innovation for companies. In the same vein, other authors believe that, in general, within academic institutions, research teams benefit from the flexibility of procedures and an organic management system that promotes agility and autonomy and membership [64, 65]. Analysis of the results of recent research [66] has shown that new techniques and methods attributable to team autonomy are an advantage for entrepreneurial performance.

Similarly, many works $[12,53]$ have shown that relational capital (RC) is a better predictor of entrepreneurial performance. It is in this vision that the results of some research $[23,25]$ has revealed that the University $\mathrm{RC}$ promotes outreach and attractiveness. Similarly, a large number of research $[4,67]$ postulate that several universities combine expertise to benefit from the synergy effect. Other works [68-70] perceive that $\mathrm{RC}$ is the capital through which universities develop interaction with the social and economic environment. According to several authors [67, 70] entrepreneurial innovation is explained by the organization's strategic anchoring on synchronized collaboration. For example, the execution of a technological innovation would be successful if the teams were interdisciplinary. Here the CR 
manifests itself in terms of the combination of resources to meet socio-economic needs. For many authors [45, 50, 52], the emergence of entrepreneurial innovation is explained by the quality of partner networks. Thus, according to these authors, for two institutions (university and higher school) that collaborate, they will create more incubators. In the same vein, some studies report that the dynamics that characterize stakeholders (e.g., teacher researchers and students) play a decisive role in entrepreneurial development [71, 72].

Under this assumption, instead of acting individually, if a university or company has a network of partners, its entrepreneurial performance would be improved.

Based on this analysis, this study is based on a framework illustrated by Figure 1.

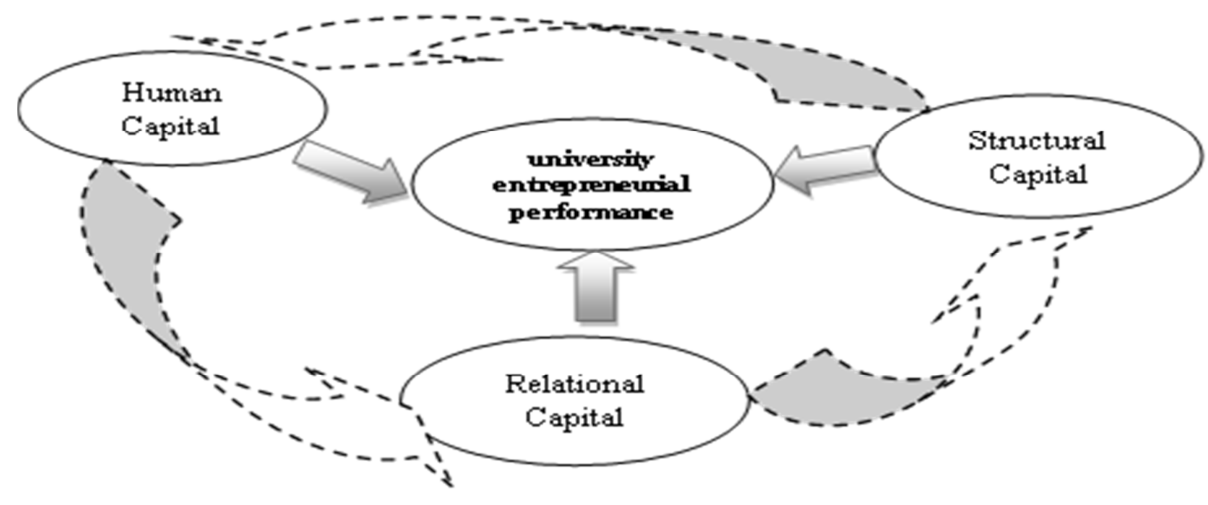

Source: summary of the author's literature, January 2020.

Figure 1. Key factors in university entrepreneurial performance.

An examination of the meaning of the arrows in Figure 1 reveals the explanatory power of the components ( $\mathrm{HC}, \mathrm{SC}$ and RC) of the IC to entrepreneurship. According to this framework (Figure 1), human capital, associated with university entrepreneurship, refers to the mobilization of entrepreneurs, continuing education policy, competence, creativity, etc.; (ii) structural capital, which promotes university entrepreneurship, is composed of technical structures, research laboratories, design offices, etc. and (iii) relational capital, associated with university entrepreneurship, refers to the network of partners, synchronized collaboration, etc. The three variables, components of intellectual capital, are retained to consider information reflecting the elements highlighted in the literature $[14,35,73,74]$. Beyond the above, most of the work is unanimous about the explanatory power of intellectual capital (human, structural, relational) of universities and the positive/negative results related to entrepreneurial innovation [4, 15, 20, 24, 50, 52, 54].

This led to the development of the theoretical model of the study shown in Figure 2.

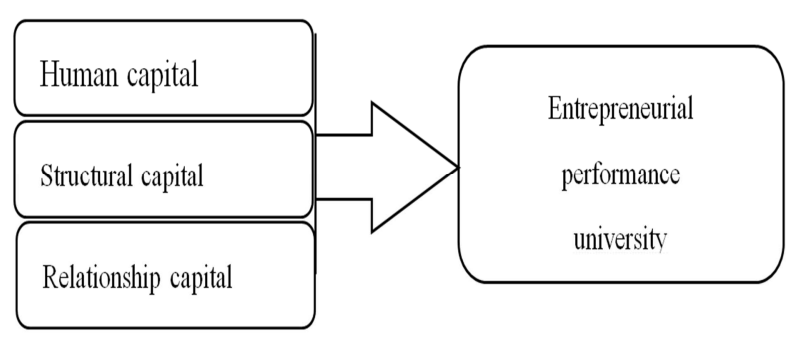

Source: literature data compilation, 2020.

Figure 2. Conceptual model.

\subsection{Development of Hypotheses}

The conceptual model of Figure 2 suggests a general hypothesis $(\mathrm{GH})$ that assumes that academic entrepreneurial performance is generated by structural capital, human capital, and relational capital. Four adjacent hypotheses are made. The first hypothesis, which promotes human capital as a predictor of academic entrepreneurial performance, is based on recent work [20, 37, 54, 74-76]. According to this research, when an organization effectively owns and manages talented and motivated researchers and students, it would see its entrepreneurship results increase. Given this relationship, the following first hypothesis is suggested.

Assumption 1: Human capital increases academic entrepreneurial performance.

The second hypothesis, comprising structural capital, is based on a few previous studies $[9,17,77]$. These studies argue that if an organization effectively manages its structural capital, it will see its entrepreneurial performance increased. Based on this relationship, the second following hypothesis is formulated.

Assumption 2: Structural capital promotes academic entrepreneurial performance.

The third hypothesis is related capital. It is inspired by the work of a few authors [45, 70] which stipulate that the development of a company's entrepreneurship is mainly due to the quality and quantity of relational capital. In the same perspective, many contributions emphasized the co-construction of an entrepreneurial ecosystem by stakeholders in the national innovation system [23, 27-29, 55-58]. Based on this relationship, the following third hypothesis is suggested.

Assumption 3: Relational capital generates academic entrepreneurial performance.

Finally, some authors report that it is rather the combination of the three components of intellectual capital that plays a decisive role in the fertilization of entrepreneurship within the organization $[9,16,17,22,41,77]$. Therefore, the fourth 
hypothesis below is proposed.

Assumption 4: The combination of the components of intellectual capital increases academic entrepreneurial performance.

To validate these hypotheses, the following sequence reflects the methodological path.

\section{Methodological Path}

\subsection{Walk}

Proponents of the theory of intellectual capital and entrepreneurship agree on the multidimensional character but also on their interdisciplinarity. Thus, proposing and testing a model of academic entrepreneurial performance based on intellectual capital calls for the mobilization of a hybrid methodology framework. Indeed, the mixed estimate recommends the generation of qualitative (open) and quantitative (closed) data to address the research problem. The reasons for this choice are three levels: (i) in general, the mixed approach is chosen for its qualitative and quantitative strengths as well as the reduction of the limits attached to it; (ii) on a practical level, methodological mixing offers the sophisticated perspective and allows access to qualitative and quantitative data (Creswell, 2013), (iii) from a procedural point of view, it is a relevant strategy that allows a more detailed understanding of the research problem. More specifically, the concomitant, interlocking approach to qualitative preponderance $[78,79]$ was used. This approach was deployed in a phase in which qualitative and quantitative data were generated simultaneously and iteratively. Priority was given to qualitative data and the mix of qualitative and quantitative data was achieved during the presentation of the results and discussion. The recommendation of such a posture is part of the reflections that research on entrepreneurship will gain enormously if it is based on a systemic and mixed approach rather than a strictly normative, positivist and hypothetico-deductive approach.

Thus, at first, the documentary analysis was deployed because it is the method par excellence to understand the different facets of intellectual capital but to identify similar terms. This consultation provided (I) a portrait of intellectual capital in an organizational setting and its explanatory power over innovation and (ii) an understanding of the main theoretical currents related to it.

In a second step, we advocated semi-direct maintenance, widely recommended and used in the field of management science [80] In this type of interview, respondents have a range of freedom to provide more detailed and complete information. Eleven semi-directive interviews, individual, face-to-face and telephone, were conducted with heads of the administrative units of four Chadian universities and a center with proven evidence of entrepreneurship: Moundou University, Mongo University, Abéché University and N'Djamena University and the National Development Research Centre (NDRC). The eleven respondents, who voluntarily agreed to take questions, came from the faculties of applied sciences, science, and business technology. They were selected because of their commitment to the entrepreneurship process on campus and with economic operators.

a. The implementation of the interview is preceded by the construction of the semi-directive interview guide, which is based on four.

b. theme 1: human capital.

c. theme 2: structural capital.

d. theme 3: relational capital.

e. theme 4: university entrepreneurship (swarming)

The four themes are divided into indicators, which have helped to develop the content of the maintenance guide (see Appendix 1: maintenance guide). Table 1 presents each theme associated with its measurement indicators.

Table 1. Indicators by theme.

\begin{tabular}{|c|c|c|}
\hline Component & Measuring indicators & Sources \\
\hline Human capital & $\begin{array}{l}\text { Level of knowledge and qualification. } \\
\text { Level and quality of experience, skill, and ability. } \\
\text { The nature and scope of achievements in relation to research results. } \\
\text { Nature of initial training. } \\
\text { Entrepreneurship training. }\end{array}$ & {$[14,35,73,81-83]$} \\
\hline Structural capital & $\begin{array}{l}\text { Corporate culture/philosophy. } \\
\text { Level ofc knowledge of standards, entrepreneurial models. } \\
\text { Quality of available databases. } \\
\text { Availability of spaces for scientific expression. } \\
\text { Level of knowledge of entities supporting entrepreneurship projects. } \\
\text { Experience in intervention-oriented research. }\end{array}$ & {$[35,44,73,81,83]$} \\
\hline Relationship capital & $\begin{array}{l}\text { City of networking. } \\
\text { Level of interaction with the economic and social environment. } \\
\text { Level of collaborative work. } \\
\text { Level of organizational agility. } \\
\text { Notoriety of student researchers to society. } \\
\text { Level of involvement in the interdisciplinary network. }\end{array}$ & {$[35,44,73,81,83]$} \\
\hline University entrepreneurship & $\begin{array}{l}\text { The nature of the startups created on the camp by researchers/students. } \\
\text { Presence of swarms held by researchers/students on campus. } \\
\text { Startup evolution rate created by researchers and students. } \\
\text { Sustainability of businesses created on the university campus. }\end{array}$ & {$[4,24,55,84,85]$} \\
\hline
\end{tabular}

Source: data compiled and adaptation of literature (author, 2020). 
It should also be noted that our respondents were graciously familiar with the four themes of the interview. This advantage favored the reach of the saturation threshold after completing the eleven interviews, mostly, out of convenience, with an average duration of twenty-eight minutes per respondent.

As far as the analysis technique is concerned, we borrowed the lexical and thematic analysis. Table 2 shows how the two qualitative analysis techniques were deployed. A grid of analysis was then developed based on the four themes from the interview guide originally developed for need. This grid was filled according to the code of the interviewees and the analysis units, which are subjected to vertical and horizontal analyses, with a summary table.

The lexical analysis and thematic content have brought out new facets of the explanatory variables. Thus, the results confirmed the dimensions of intellectual capital that explain entrepreneurial performance. Similarly, lexical and content analyses have helped identify the words and themes frequently mentioned by university administrative units.

Table 2. Qualitative Analysis Techniques.

\begin{tabular}{lll}
\hline Nature of qualitative analysis & Components & Relevance indicators \\
\hline \multirow{2}{*}{$\begin{array}{l}\text { Lexical } \\
\text { Whematic }\end{array}$} & Words used; phrases come out & $\begin{array}{l}\text { The type and quality of vocabularies used. } \\
\text { e.g., frequency of word appearance, the average number of words per sentence, etc. } \\
\text { Thematic cutting } \\
\text { e.g., frequency of appearance of themes, frequency of association }\end{array}$ \\
\hline
\end{tabular}

Source: data compiled and adaptation of literature (author, 2020).

Third, the data were produced by survey conducted (on a 5-point Likert scale), from December 2019 to February 2020. The questionnaire (see Appendix 2) is, consisting mainly of indicators extracted from the literature and data from exploratory interviews. The first version of the questionnaire was used to pretest 12 respondents consisting of laboratory managers, startup managers and entrepreneur researchers/students from three incubators/essays. These respondents, who still remain in the fold of their university, are selected on the basis of criteria of expertise in entrepreneurship and knowledge transfer. Comments and opinions from the test were borrowed to improve and adopt the final version of the questionnaire and then submit to respondents. Table 3 reports on the characteristics of interviewees and survey respondents.

Table 3. Respondents Profile.

\begin{tabular}{llll}
\hline Respondents & Disciplines/course & number & proportion (percentage) \\
\hline Researchers & Marketing, accounting, finance, management and administration of small and medium-sized & 31 & 17,4 \\
student & organizations, human resource management, IT applied to management, IT, and telecom. & 148 & 82,59 \\
Total & & 178 & 100 \\
\hline
\end{tabular}

Source: data compiled from the interview guide, (author, 2020).

The path of determining the sample size for the survey borrows the recommendations of Igalens and Roussel, who postulate that the sample size should be proportional to the number of items, five to ten times more respondents than there are items describing the buildings under study [86] Twenty items are generated to appreciate the five built of the model. Thus, we have $5 \times 20$ and $10 \times 20$, or between 100 and 200, we opted for the highest terminal or No. 200 individuals considered to be reporting units. We have adopted the sampling approach with reasoned choices, favoring quota and convenience methods for the qualitative part. As mentioned above, the qualitative approach is mobilized in main mode and, non-random sampling suits well with "real life" and more practical surveys. On the other hand, in terms of the quantitative aspect, we preferred random cluster sampling. To meet this approach, we have put forward the criteria for types of entrepreneurship (economic/financial, social, environmental/societal).

The questionnaire was sent directly to respondents via email. After three recalls, a total of 178 questionnaires were received or $71.2 \%$ was used in the analysis. ANOVA tests were conducted to examine possible non-response bias, as recommended by Armstrong and Overton [87]

\subsection{Variables and Measurements}

The measures adopted in our research are based on several previous qualitative and quantitative studies $[8,9,12,14,17$, $18,21,22,35,37,40,50,54,73,81-83,88,89]$. We have adapted them to the context of Chadian universities.

Independent variables: We borrowed the indicators commonly used in the appreciation and measurement of variables, human capital, structural capital, and relational capital:

a. for human capital, we have prioritized (i) knowledge and qualification (ii) the level and quality of experience, entrepreneurship skill (swarming), (iii) the nature and scope of achievements related to research results (iv) the nature of initial training, (v) entrepreneurship training or project management.

b. about structural capital, we have selected (i) the university's culture/philosophy in terms of entrepreneurship (ii) knowledge of the standards, models, and fertile soils for entrepreneurial emergence (iii) availability of databases conducive to business creation 
(iv) knowledge of the availability of spaces for scientific and technical expressions, (v) knowledge of entities supporting entrepreneurship projects (vi) research experience in project or research intervention.

c. for relational capital, we opted for (i) the quality of networking (ii) the level of interaction with the economic and social environment (iii) the level of collaborative work (iv) organizational agility, (v) the notoriety of student researchers with society (vi) the level of involvement in the interdisciplinary network.

The studies explored used Likert's five-point scales (ranging from (1) disagree at all to (5) quite agree. The reliability of the scale is $0.97 \%[9,17,18]$.

Dependent variable (academic entrepreneurial performance): the focus is on (i) the creation of social and societal incubators (ii) socio-economic startups (iii) the implementation of climate change projects and (iv) ICT incubators. The data were obtained using the Likert scale ranging from (1) disagree at all to (5) quite agree. The reliability of the scale is 0.77 .

\section{Empirical Results}

\subsection{Role of Chadian Universities in the Construction of Intellectual Capital}

Intellectual capital is specific to each organization [20] Chadian universities are no exception to this principle. Thus, in the process of building intellectual capital, it appears that the value and importance of this capital are determined by its potential contribution to the main objectives pursued by the university. Therefore, there is no homogeneous way of building academic intellectual capital, but its importance stems from the breadth of the three core missions of any university, including teaching, research and innovation, and the provision of services to the community. Over the past decade, Chadian universities have radically reformed the education system from traditional to a renewed approach structured by The Bachelor of Science (LMD). To support the implementation of this system, training units in project management, entrepreneurship and business creation have been introduced into the educational programs. Similarly, administrative units dedicated to research and innovation have been created at each university. In addition, laboratories structured by research units have been created with explicitly formulated axes. These structures have varied areas of research, but all aim at socio-economic development by promoting studies and research, which are subordinated to innovation in all its senses. Then, workshops and training seminars in quality assurance, research intervention, entrepreneurship was organized for the benefit of teacher researchers and professionals. Finally, universities and research institutes are grouped into a consortium, and have promoted the diversification of partnerships and the training of trainers. Thanks to networking, Chadian universities are more established at the sub-regional level through involvement in scientific and entrepreneurial events. These include: (i) the organization of the 17th Symposium on the Pharmacopeia of Traditional Medicine in 2013; (ii) the $42^{\text {nd }}$ Board of Directors of the Inter-State School of Veterinary Sciences and Medicine in Dakar [90] These initiatives have fostered the creation of databases and competitive intellectual capital, real assets to further fertilize entrepreneurship in all its facets.

\subsection{Results from Interviews and Surveys}

Interviews and surveys have encouraged the production of verbatim. Table 4 shows the portrait of verbatim.

Table 4. Verbatim.

\begin{tabular}{ll}
\hline Variables tested & Verbatims \\
\hline \multirow{3}{*}{ Human capital } & I think our staff and students have knowledge and qualifications, \\
& There have been achievements that have been and have been related to the results of the research. \\
& Teachers and students received initial training to start businesses. \\
& Within the faculties, there are entrepreneurship training programs. \\
& There are support and support structures in the knowledge of entrepreneurial models. \\
& Teachers and students have a good level of fertile soil knowledge for entrepreneurial development. \\
& Our university has knowledge to align it with development strategies. \\
There are many spaces for scientific expressions such as amphitheaters, scientific journals, etc. & Our university knows several organizations that fund and support entrepreneurship projects. \\
Experience in intervention-oriented research. & Over the past five years, we have developed a network of partnerships that contribute to innovation. \\
& Thanks to our open innovation and business support policy, the level of interaction with the economic and social \\
environment has generated more than ten Start-ups. & The level of collaborative work between researchers-student-economic operators is higher, \\
top management has developed a good level of organizational agility among researchers. & The reputation of our student researchers with the company is of remarkable regional significance. \\
& Our researchers and students are heavily involved in interdisciplinary networks.
\end{tabular}

Source: excerpts from interview results (author, 2020).

The analysis of the verbatim in Table 4 identified new concepts that take the place of emerging variables, real factors that explain the emergence of the entrepreneurial. Table 5 reports on the result of the verbatim example. 
Table 5. Verbatim and emerging variables (No. 16).

\begin{tabular}{llll}
\hline Variables & Verbatim & Emerging variables \\
\hline $\begin{array}{l}\text { Human } \\
\text { capital }\end{array}$ & $\begin{array}{l}\text { Good university and professional qualifications; Applied research/intervention } \\
\text { skills the mobility of teachers and students; research combining theory and }\end{array}$ & $\begin{array}{l}\text { Continuing practical training; Training workshops in } \\
\text { entrepreneurship and business language. }\end{array}$ \\
$\begin{array}{l}\text { practice played a decisive role (Interview 2, 5.8.9) } \\
\text { Capital }\end{array}$ & $\begin{array}{l}\text { Some structures and facilities for research, vocational training; organization of } \\
\text { cultural, professional, cultural, etc. events (Interview. 1, 3, 4.7). }\end{array}$ & Presence of laboratories, design offices; empowerment \\
Relationship & Constructive relationships with society (collaboration in sanitation, hygiene, & Business network, promote business co-creation; \\
Capital & reforestation, etc.); Business-media-university collaborations have created & university entrepreneurship funding agencies; promote \\
& research and entrepreneurship opportunities. (Interview 6, 5.7.9, 10) & co-creation of a business. \\
\hline
\end{tabular}

Source: Summary of Interview Results, 2020.

Analysis of the data in Table 5 reveals the importance of the components of intellectual capital as playing a decisive role in university swarming.

1) Quantitative Earnings Trends

In general, our respondents perceive human capital, structural capital and relational capital as factors that explain the development of university entrepreneurship. Indeed, they report that human capital is sensitive to entrepreneurship with an average of 4.5 out of 5 (Etc. $=1.87)$. They state that structural capital is conducive to university entrepreneurship growth with an average of 4.1 out of $5(E c . T .=1.63)$. Second, they mention that relational capital is richly diversified and contributes to entrepreneurial performance with an average of 4.7 out of 5 (Ec.T. $=1.45)$. Finally, they point out that the fact that their institution enriches the three capitals plays a decisive role in the creation of incubators, startups of various kinds with an average of $4.8(E c . T=1.89)$. In short, respondents see their administrative unit of belonging as more inclined to university entrepreneurial culture. These results are, of course, all positive, although interviews emerge, some divergent points of view include some respondents who deplore the low level of structural capital to support and accompany students and researchers' entrepreneurs. The results also show that respondents share their institution's efforts in investing in human capital. Indeed, they point to initiatives in the field of organizational agility, training, etc. as aspects to be promoted to further promote the development of university entrepreneurship.

Finally, Table 6 presents strong correlational results between the components of intellectual capital and academic entrepreneurial performance. Indeed, considering each variable, it is relational capital that has the strongest positive correlation $(r=0.93 ; p<.01)$ with entrepreneurship. Second, human capital is the second variable strongly correlated $(r=$ 91, $\mathrm{p}<.01$ ) with entrepreneurial performance. Finally, structural capital comes in third place with a positive correlation $(\mathrm{r}=0.85, \mathrm{p}<.01)$. However, it is the combination of the three variables that emerges as the variable more strongly correlated $(\mathrm{r}=0.96 ; \mathrm{p}<.01)$ to academic entrepreneurial performance. These results converge with the interview data in Table 4, which thus confirm the research hypotheses.

Then, we determined on the average, the standard deviation, and the correlation coefficient, respectively.

Table 6. Averages, standard deviations, and correlations between variables $(n=278)$.

\begin{tabular}{|c|c|c|c|c|c|c|}
\hline Variables & $\begin{array}{l}\text { Medium and Type } \\
\text { Gap (Ec.T.) }\end{array}$ & $\begin{array}{l}\text { University } \\
\text { entrepreneurship }\end{array}$ & $\begin{array}{l}\text { Human } \\
\text { capital }\end{array}$ & $\begin{array}{l}\text { Structural } \\
\text { capital }\end{array}$ & $\begin{array}{l}\text { Relationship } \\
\text { capital }\end{array}$ & $\begin{array}{l}\text { Combination } \\
\text { (intellectual capital) }\end{array}$ \\
\hline University entrepreneurship & $4,3(1,91)$ & 1 & & & & \\
\hline Human capital & $4,5(1,87)$ & $0,91 * *$ & 1 & & & \\
\hline Structural capital & $4,1(1,63)$ & $0,85 * *$ & $0,89 * *$ & 1 & & \\
\hline Relationship capital & $4,7(1,45)$ & $0,93 * *$ & $0,91 * *$ & $0,74 * *$ & 1 & \\
\hline Combination (intellectual capital) & $4,8(1,65)$ & $0,96 * *$ & $0,96 * *$ & $0,81 * *$ & $0,56 * *$ & 1 \\
\hline
\end{tabular}

$* * \mathrm{p}<, 01$

Source: traitement IBM SPSS 23.0, 2020.

In conclusion, if each university effectively improves its human capital, structural capital, and relational capital during every hour of its operation, it will see its entrepreneurial performance improve.

2) Testing hypotheses

To test the four hypotheses, and as our methodological approach allows us, we present, simultaneously, the verbatim from the interviews and the results of the step-by-step regression. Indeed, the step-by-step regression method allows verification of the variation in the $\mathrm{R}^{2}$ coefficient of each explanatory variable added to the model equation [91] In addition, the coefficients "b" and " $\beta$ " are used. We analyzed the data using SPSS 23.0 software.
Assumption 1: Human capital increases academic entrepreneurship performance.

On the qualitative side, respondents were unanimous in the importance of the contribution of human capital (HC) in university entrepreneurial performance (UEP):

"We are significant players in the development of entrepreneurship, thanks to the establishment of the Faculties of Business Science and Technology, Computer Science and Telecommunications, etc., which have trained young executives, who have set up, since 2015, more than 18 incubators in the fields of information systems in health, education, food safety, street addressing, and specialist HR design offices that provide training for business staff. The 
creation of several startups of the quality of our human capital. Then, thanks to this capital, we effectively conducted our current academic practices, including the creation of knowledge, clusters, innovative and autonomous entrepreneurial activities, etc. through competent research and student teachers. In addition, we have provided technical support through innovations leading to commercialization. Finally, we have revitalized the entrepreneurial ecosystem through weeks dedicated to science, conferences, seminars, science, and technology hubs, we have developed a guide on entrepreneurial policy... (EntrUniv. 3, 5.6).

These statements suggest that knowledge and the competence of human capital have amply contributed to the implementation of both technological and social entrepreneurship projects.

Quantitatively, human capital (HC) significantly predicts university entrepreneurial performance (UEP). Indeed, $\mathrm{R}^{2}$, which estimates the robustness of the proposed model, shows a significant regression $\left(\mathrm{R}^{2}=0.21, p<.00\right)$ between $\mathrm{HC}$ and UEP. Otherwise, the $\mathrm{CH}$ accounts for $21 \%$ of the variation in the UEP of the universities studied. While the coefficient " $\mathrm{b}$ " = 0.19 means that with each improvement in the HC quality scale, the predicted UEP increases. Similarly, the beta standardized coefficient $(\beta=0.23)$ measuring the $\mathrm{HC}$ variable shows that this variable contributes to the prediction of UEP. The value of the T-test $(\mathrm{t}=8.62 ; \mathrm{p}, 00)$ indicates that $\mathrm{HC}$ 's contribution to the explanation of the UEP level is statistically significant. These results confirm the hypothesis1 of HC's prediction of UEP.

Assumption 2: Structural capital promotes academic entrepreneurial performance.

Qualitatively, the opinion of university administrative units is the following:

«... we are state institutions, apart from universities (laboratories) that have promoted the creation of more than 11 incubators and have supported the holders of technology incubators and startups: I can cite the cases of (i) Smart Village Linia in 2017; (ii) Acting for Intelligent Agriculture in the Sahel (AIS) in 2016 and (iii) Acting for Responsible Food Security (ASAR) in Chad in 2015." The creation of these companies is made possible by the computerized database, the business creation guide on university campuses developed in partnership with four faculties and economic operators (EntrUniv. 1, 2, 3, 4.6).

The interview with those responsible for the so-called trials revealed that the structural capital components played a decisive role in the various phases (identification, design, implementation, and consolidation) of these startups. Universities, through the National Development Research Centre (NDRC) and several laboratories, have also played an effective role in the development of university entrepreneurship:

«... I think that as an institution of the state, we have played our part in the development of technological spin-offs. We have transformed science and knowledge into goods and services with commercial value. In addition, we offer infrastructure that promotes commercialization, by developing training programs that promote entrepreneurship: since 2015, we have set up, through univalor, more than four ICT incubators/accelerators applied to health, education, etc." (EntrUniv. 1, 3, 4.6).

Documentary research has identified the NDRC's main research and innovation missions. (Https://www.cnar-cnrd.org):

a. Ensure scientific research, results enhancements, and technical innovation.

b. Supporting higher education and research institutions.

c. Serve as an interface between research institutions and development promoters.

d. Collect, centralize, and update scientific and technical documentation.

e. Making it easier to flow information.

f. Edit and disseminate scientific work.

g. Develop a database of human, financial and material resources for research.

h. Support the training of research teachers.

Quantitatively, structural capital (SC) also predicts university entrepreneurial performance (UEP). Indeed, according to the data in Table 2, the $\mathrm{R} 2$ coefficient shows a significant regression $(\mathrm{R} 2=.34, \mathrm{p}<.01)$ between the $\mathrm{SC}$ and the UEP. Otherwise, the CS accounts for $13 \%$ of the variation in PEU in the three universities studied. While the coefficient $" b "=.28$ means that with each improvement in the CS quality scale, the level of UEP increase. Similarly, the beta coefficient $(\beta=0.22)$ shows that the SC contributes to the prediction of PEU. The value of the T-test $(t=8.72)$ indicates that this contribution to the explanation of the UEP level is significant. Such results confirm hypothesis 2 .

Assumption 3: Relational capital breeds university entrepreneurship.

The views of some academic leaders suggest that the quality of relational capital has fostered the implementation of entrepreneurship projects:

"For us here, the spin-forward projects illustrating some of our axes are revealing. The Consortium of Universities demonstrates interdisciplinary and collaborative research models (The Great Chadian Lake Ecosystems (GCLE) project that extends beyond Chad. In our opinion, this is one of the consequences of our relational capital, if not the consequence demonstrating entrepreneurial excellence, to be prioritized to ensure social development. In fact, Chad's sufficient entrepreneurial excellence is very ephemeral, whether for scientific publications (more than 40 publications) or industrial, social, and environmental innovation initiatives aimed at solving the problem of climate change. When we remember the context of the implementation of GCLE, the fruit of Franco-Chadian cooperation and collaboration between researchers from more than 25 academic institutions, we can only praise the work of builders such as the Technical Adviser of the Ministry of Higher Education, the Director of Scientific Research, the Vice-Rectors in charge of research and innovation... (EntrUniv. 4.5, 6) 
A review of these statements makes it clear that interdisciplinarity and networking have paid off: the value of innovation and relational capital. This is what one respondent said:

«... in my opinion, this kind of interdisciplinary collaboration around research and entrepreneurship projects needs to be replicated, especially if we want to develop the center of excellence in university entrepreneurship within the consortium of universities in Chad. We can expand such projects in renewable energy, electrification, transport, etc. sector" (EntrUniv. 3.)

Quantitatively, the RC also predicts university entrepreneurial performance (UEP). The $\mathrm{R}^{2}$ coefficient shows a significant regression $\left(\mathrm{R}^{2}=.63, \mathrm{p}<.00\right)$ between the $\mathrm{RC}$ and the UEP. Otherwise, the RC accounts for $29 \%$ of the variation in UEP in the universities studied. While the coefficient " $b$ " $=0.31$ means that with each improvement in the cr quality scale, the level of UEP increase. Similarly, the beta coefficient $(\beta=0.34)$ shows that the RC contributes to the prediction of UEP. The value of the T-test $(t=8.77)$ indicates that this contribution to the explanation of the PEU level is significant. Such results confirm hypothesis 3 .

Assumption 4: Intellectual capital increases the overall academic entrepreneurial.

Qualitatively, the heads of administrative units at the four universities believe that intangible capital is important in the knowledge economy, which promotes the development of entrepreneurship and innovation:

«... but it is obvious, if today we are witnessing a plethora of stars up, incubators, in all the city's housing the university institutions, this result, in large part, from the substantial investments that have helped to strengthen the human, structural and relational resources of universities and research institutions... ». (EntrUniv. 3.5, 6)

In the same perspective, other leaders recognize that the agile environment promotes entrepreneurship and innovation projects:

«... I am not an intellectual capital specialist, but according to the testimony of some of my collaborators, it seems that setting up the entrepreneurial culture through training in business creation and research-intervention techniques promotes creativity but also ensures the continuous engagement of our employees in their position and mission. And our social partners support us in this approach... (Between Union. 10).

Finally, according to Table 7, intellectual capital (CI), through its three combined components, predicts university entrepreneurial performance (UEP). The $\mathrm{R}^{2}$ coefficient $\left(\mathrm{R}^{2}\right.$ $=.85, p<.00$ ) shows a significant regression between the IC and the UEP. This means that the IC accounts for $85 \%$ of the variation in UEP in the four universities studied and the $\mathrm{N}$ NDRC. On the other hand, the coefficient " $b "=0.19$ means that with each improvement in the quality of the IC, the level of the PEU increases. Similarly, the beta coefficient $(\beta=0.33)$ shows that the IC contributes to the prediction of the UEP. The value of the T-test $(t=8.92)$ indicates that this contribution to the explanation of the level of the PEU is significant. Such results confirm hypothesis 4 .

In the end, although each variable significantly predicts UEP, it is the combination of the three components that plays a decisive role $\left(\mathrm{R}^{2}=.85\right)$ in the prediction of UEP. However, all four assumptions are supported by the results.

Table 7. Predictors of University Entrepreneurial Performance (No. 178).

\begin{tabular}{llllll}
\hline Variables & $\mathbf{R}^{\mathbf{2}}$ & $\boldsymbol{B}$ & $\boldsymbol{B}$ & $\boldsymbol{t}$ \\
\hline Constant & & 2,17 & 2,37 & \multicolumn{1}{c}{, 00} \\
Human capital & 0,21 & 0,19 & 0,23 & 8,62 & 8,72 \\
Structural capital & $0,34(0,13)$ & 0,28 & 0,32 & 8,77 \\
Relationship capital & $0,63(0,29)$ & 0,31 & 0,34 & 8,82 &, 00 \\
combination & 0,85 & 0,19 & 0,33 &, 00 \\
\hline
\end{tabular}

Source: treatment IBM SPSS 23.0, 2020.

\section{Discussion, Implications, Limitations, and Perspectives}

\subsection{Discussion}

Our model has proven its worth as a conceptual framework because intellectual capital, through its three components, accounts for $85 \%$ of the variance in university entrepreneurship, far exceeding the results achieved in previous work $[1,4,9,12,18,52-54]$. Previous research has suggested that knowledge-based resources should be necessary to create an entrepreneurial activity [59, 60]. A theoretical explanation of the expected relationship between intellectual capital and entrepreneurial performance is based on resources that suggests that a sustainable competitive advantage is achieved through the control of unique and inimitable assets [61-63]. This study uses resource theory to show that knowledge, knowledge (intellectual capital) assets are effective in achieving the development and growth of entrepreneurial activities and innovation such as new product creation, business creation, etc.

The result of the model shows that intellectual capital has a positive effect on university entrepreneurial performance (UEP). More specifically, relational capital has a significant effect on UEP and thus appears as the best predictor. This result can be explained by the relationship between the partners, the development of business networks, where maintaining a good relationship is fundamental. Similarly, such an outcome can be explained by the fact that universities, like any other institution, are not islands. Therefore, an organization must build good relationships with its stakeholders, customers, and suppliers to improve its entrepreneurial performance. Finally, intra, and inter-organizational resources have a strong explanatory power 
over the organization's performance. Human capital also significantly affects UEP, which means that good quality human resources are a key element in knowledge-intensive organizations as skilled workers create and innovate new products and services.

In addition, our results support a positive relationship between intellectual capital and entrepreneurial performance $[9,16,18,22,41,52-54]$. Intellectual capital is one of the most important sources for achieving competitive advantages. Based on resource-based vision, organizations gain a competitive advantage and superior performance through the acquisition, ownership and use of strategic assets that are essential to developing a competitive advantage and achieving good performance [63] The result of the model shows that not all components of intellectual capital have the same effects on academic entrepreneurial performance. In fact, the relationship between human capital, relational capital and UEP is stronger. The robustness of this relationship is not necessarily due to the correlation between the two independent variables involved. Thus, the structure of hypotheses 1 and 3 does not allow such a relationship to emerge. These results corroborate, however, those of the authors [9] who report that many qualified employees help the organization generate internal knowledge and absorb external technological knowledge. For example, universities should acquire and manage employees with higher levels of intellectual capital in exchange for better innovation and entrepreneurial performance $[9,17,18]$. The authors also argue that the best relationships with partners improve when an organization invests more in relational capital, which improves the exchange and sharing of knowledge. An organization needs to build good relationships with its stakeholders to improve organizational performance.

The results of this study support the views of several other authors that there is a positive association between entrepreneurial performance and competitive intellectual capital $[4,15,20,24,50,52,54]$. The results confirm the proposition that the two concepts are indeed interdependent and the PEU is important to improve the visibility and notoriety of the university. Based on these findings and discussion, theoretical and managerial implications can be considered and avenues for research can be suggested.

\subsection{Implication}

Due to its maneuvering terrain of universities, our research confirms the majority of previous studies $[9,17,18,22]$ but also goes against other previously explored business-centric. Therefore, the results obtained demonstrate the known interest in future studies on relational capital, human capital, and structural capital. Secondly, the fact that relational capital appears to be the best predictor of entrepreneurial performance leads entrepreneurs to create, regularly enrich their business network from the conceptual phase of their business project. This strategy would help to improve the quality of the product to adapt it to consumer expectations. Such an approach would ensure the success of the newly created company. Moreover, the intensification of university entrepreneurship could be generated by the realization of seminars, science fairs, green weeks aimed at promoting entrepreneurship. Therefore, it would be beneficial for universities to frequently initiate support actions focused on relational investments.

Beyond the above, this research brings out new theoretical paths. Indeed, clarifying the different types of intellectual capital promotes refinement in understanding their contribution to university entrepreneurial development. This approach, the model initially suggested as a reflection of this, had never been so rigorously demonstrated using empirical qualitative and quantitative data. Thus, academic entrepreneurial performance has necessitated the impact of a specific component of intellectual capital. As a result, we consider, among other things, the following theoretical avenues: (i) resource theory $[61,62]$ and (ii) network theory. Barney highlighted the importance of managing an organization's resources to make it more competitive in a "red ocean." While supporters of the prospects of the networks have proved its importance. As a result, research entrepreneurs and students are invited to perpetually co-build their intellectual capital and activate their business network to adapt to the challenges of the reality on the ground. Because the design, implementation and development of a socio-economic activity use norms and rules that are not very similar to those learned in a scientific setting.

This study showed that all three components of intellectual capital contribute to the development of university entrepreneurship. It thus shows the interest of exploring, in the future, the opportunities offered by the perspectives of networks that proves relevant to generate global entrepreneurial success. Similarly, the importance of the network as an indicator of relational capital has been highlighted to explain the entrepreneurial growth. It appears that universities, through researchers, have developed networks of partnerships that have enabled us to set up business projects in the information technology, climate change, agriculture, etc. From this perspective, resource-based approaches and partner networks appear to be relevant theoretical foundations for explaining the relationship between intellectual capital and entrepreneurial performance. It is also in the same vision as some authors [53, 54] discussed relational capacities to inform the process of creating networks of actors while others [41, 54] focused on relational capabilities in the rise of startups.

\subsection{Bounds}

The results of this study present limitations and points that require further research. First, due to the unavailability of the data, longitudinal research was not viable for this study. Similarly, university entrepreneurial performance is evaluated in terms of the creation of socio-economic activities. As a result, this study adopted a cross-cutting research concept and examined universities, through researchers and students, at some point. Second, only subjective information from the interview guide and questionnaire is used to measure the results of the four universities, thus limiting the scope of this research. Although this type of information is commonly used 
in studies, the introduction of other measures from objective sources to replicate these results would be interesting. Second, other factors that were not included in this study are also likely to affect intellectual capital and entrepreneurial performance. Finally, the sample size is small but diverse and, as a result, provides a representative picture of university entrepreneurship in Chad. Data production takes a mixed approach to reducing the weaknesses of each method.

\subsection{Perspectives}

The results showed the robustness of the explanatory power of intellectual capital over entrepreneurial performance for the four Chadian universities. If several works [20, 54] have proven the remarkable link between the dimensions of intellectual capital and entrepreneurial performance, others have, on the other hand, developed the stakes of co-building an entrepreneurial ecosystem [23, 27-29, 55-58]. It is necessary to consider as significant research perspectives to better understand the capacity of the co-construction of entrepreneurial intellectual capital. In addition, future studies could use objective measures of entrepreneurial performance to strengthen research design. Finally, future studies could introduce mediating variables into the relationship between intellectual capital and entrepreneurial performance, improving understanding of how intellectual capital affects the entrepreneurial.

\section{Conclusion}

The two questions that have presided over this research need to be answered: which components of intellectual capital have a strong explanatory power over academic entrepreneurial performance? Our results show that universities that invest in their intellectual capital are able to design and implement several technological, socio-economic, and environmental entrepreneurship. It is above all the combination of the three components that plays a decisive role in the fertilization of entrepreneurship. As a result, our assumptions are consolidated. So intellectual capital is the best lever for entrepreneurship.

Specifically, two areas seem relevant to increase university entrepreneurial innovation in Chad: the first axis would be to raise awareness among universities to accept change, to take risks. Strategies to achieve this include (a) the design of training programs that would prepare "entrepreneurial-innovative students" who are ready to identify and create new business opportunities; b) teaching the theories and practices of contemporary management, creativity, and the arts. The second axis would be to promote discoveries, scientific applications, support for experimentation and exploration as a cornerstone of innovation. It is essential to focus on building applied research capacity, research and intervention while fostering partnerships.

In any case, entrepreneurship is a very useful area that relies on the quality of the organization's intellectual capital, and that no university has any fear of engaging in it, regardless of size and resources. If it invests conscientiously in improving its intellectual capital, it does not have to worry about the result. It can be sure to be one of the best performing universities in its ecosystem.

Table 8. Recommendations follow-up plan.

\begin{tabular}{|c|c|c|}
\hline Recommendation & Implementation strategies & arget \\
\hline Awareness of change & $\begin{array}{l}\text {-Improving the quality of human capital through the teaching of entrepreneurship education; } \\
\text {-Create training programs in collective intelligence and dynamic abilities. }\end{array}$ & \\
\hline $\begin{array}{l}\text { Promotion of scientific discoveries and } \\
\text { support for experimentation. }\end{array}$ & $\begin{array}{l}\text {-Enrichment of relational capital through university-business-NGO-State partnerships. } \\
\text {-Organize fairs and scientific weeks } \\
\text {-Creation of experimental parks }\end{array}$ & $\begin{array}{l}\text { Heads of } \\
\text { administrative }\end{array}$ \\
\hline $\begin{array}{l}\text { Governance of research and innovation } \\
\text { projects }\end{array}$ & $\begin{array}{l}\text {-Improvement of structural capital through the implementation of standards, benchmarks, } \\
\text { methods and models for managing research and innovation projects. }\end{array}$ & $\begin{array}{l}\text { units, teacher - } \\
\text { researchers, }\end{array}$ \\
\hline $\begin{array}{l}\text { Promotion of the culture of technology } \\
\text { transfer and innovation }\end{array}$ & $\begin{array}{l}\text {-Define and teach the approaches of academic, technological and university entrepreneurship, } \\
\text {-Develop the call for projects approach to entrepreneurship. }\end{array}$ & $\begin{array}{l}\text { researchers, } \\
\text { students and }\end{array}$ \\
\hline $\begin{array}{l}\text { Support for the development of culture } \\
\text { based on Action Research }\end{array}$ & $\begin{array}{l}\text {-Foster the emergence of leadership and excellence in research, innovation and development. } \\
\text {-Set up a directorial architecture for the orientation and management of projects. }\end{array}$ & NGOs \\
\hline $\begin{array}{l}\text { Implementation of managerial architectures } \\
\text { dedicated to entrepreneurship }\end{array}$ & $\begin{array}{l}\text {-Create engineering training courses and put in place managerial architectures to promote } \\
\text { academic entrepreneurship, technological entrepreneurship and university entrepreneurship. }\end{array}$ & \\
\hline
\end{tabular}

Finally, we must mention the importance of going much further in investigating intellectual capital and university entrepreneurship, on entrepreneurial modalities and practices. Research needs a better understanding of supporting practices for researchers' entrepreneurs, student entrepreneurs during the deployment of the entrepreneurial life cycle. In any case, the major expectations are for investments in training, coaching/coaching, organizational agility to promote the quality of intellectual capital as well as its explanatory power over the path from research to innovation through future research.

In order to promote the implementation of the elements of the conclusion and their follow-up, the formulation of recommendations accompanied by a plan of action is essential. The following lines reflect the results.

1. Recommendation 1: educate institutes and universities to accept change, to take risks.

2. Recommendation 2: promote discoveries, scientific applications, support for experimentation and exploration as a cornerstone of innovation.

3. Recommendation 3: strengthen capacity in research and innovation project governance in relation to priority sectors;

4. Recommendation 4: promote a culture of technology transfer and innovation focused on results and benefits. 
5. Recommendation 5: support the development of culture based on Research-Action-Development;

Recommendation 6: Create engineering training courses and put in place managerial architectures to promote academic entrepreneurship, technological entrepreneurship and university entrepreneurship.

These recommendations are translated into strategies and targets. Table 8 reports the results.

\section{References}

[1] Nakagawa, K., et al., A University-Industry Collaborative Entrepreneurship Education Program as a Trading Zone: The Case of Osaka University. Technology Innovation Management Review, 2017.7 (6): p. 1-13.

[2] Scandura, A., University-industry collaboration and firms' R \& D effort. Research Policy, 2016. 45 (2016): p. 1907-1922.

[3] Bessieux-Ollier, C. and É. Walliser, Le capital immatériel État des lieux et perspectives. Revue française de gestion 2010 . 2010 (207): p. pages 85 à 92.

[4] Damsgaard, E. F. r. and M. Thursby, University entrepreneurship and professor privilege. Industrial and Corporate Change, 2013. 22 (1): p. 183-218.

[5] Garel, G. and E. Mock, The Innovation Factory. 2016.

[6] Abbadi, N., Transfert des technologies. Quel model pour l'Afrique ? Triennale de l'éducation et formation en Afrique, Association pour le développement de l'éducation en Afrique (ADEA), Ouagadougou, Burkina Faso, 2012. 2012: p. p. 1-30.

[7] Bug, A. and D. Randet, Valorisation économique de la recherche publique. ANRT-Valoris-FutuRIS, 2009. 29/09/2009 (2009): p. p. 1-19.

[8] Yaseen, S., D. Dajani, and Y. Hasan, The impact of intellectual capital on the competitive advantage: Applied study in Jordanian telecommunication companies. Computers in Human Behavior 2016. 62 (2016): p. 168-175.

[9] Abdullaha, D. F. and S. Sofiana, The Relationship between Intellectual Capital and Corporate Performance. Procedia Social and Behavioral Sciences 2012. 40 (2012): p. 537-541.

[10] Nakagawa, K., et al., A University-Industry Collaborative Entrepreneurship Education Program as a Trading Zone: The Case of Osaka University. Technology Innovation Management Review 2017. 7 (6): p. 38-49.

[11] Bardinet-Evraert, F., Capital intellectuel, gouvernance et facteurs institutionnels Dans Variations autour des PME et entreprises de taille intermédiaire EMS 2019 (2019): p. 127 à 135.

[12] Berzkalnea, I. and E. Zelgalve, Intellectual capital and company value. Procedia - Social and Behavioral Sciences, 2014. 110 (2014): p. 887-896.

[13] Aramburu, N. and J. Saenz, Structural capital, innovation capability, and size effect: An empirical study. Journal of Management \& Organization, 2011. 17 (2011): p. 307-325.

[14] Cadet, I., La mesure du capital humain: comment évaluer un oxymore? du risque épistémologique à l'idéologie de la certification. Question(s) de management 2014. 1 (5): p. 11-32.
[15] Marvel, M., Human Capital and Search-Based Discovery: A Study of High-Tech Entrepreneurship. Entrepreneurship theory and practice, 2013. 10 (2013): p. 403-419.

[16] Unger, J., et al., Human capital and entrepreneurial success: A meta-analytical review. Journal of Business Venturing, 2011. 26 (2011): p. 341-358.

[17] Ahmad, S. b. and A. M. Mushraf, The Relationship between Intellectual capital and Business Performance: An empirical study in Iraqi industry. International Conference on Management and Artificial Intelligence 2011 (2011): p. 1-6.

[18] AL-Duajaili, M. A. A., Influence of Intellectual Capital in the Organizational Innovation. International Journal of Innovation, Management and Technology., 2012.3 (2): p. 128-135.

[19] Brulhart, F., G. Guieu, and L. Maltese, Théories des ressources: Débats théoriques et applicabilités. Revue française de gestion, 2010. 5 (204): p. 83 à 86.

[20] Maltseva, A., Intellectual capital of universities and regions: a qualitative analysis of mutual influence's directions. Revista ESPACIOS, 2018.39 (20): p. 18-31.

[21] Zerenler, M., S. B. Hasiloglu, and M. Sezgin, Intellectual Capital and Innovation Performance: Empirical Evidence in the Turkish Automotive Supplier. Journal of Technology Management \& Innovation, 2008. 3 (4): p. 31-40.

[22] Nhon, H. T., B. Q. Thong, and N. V. Phuong, The impact of intellectuel capital dimensions on vietnamese information communication technology performance: a mediation analysis of human and social capital. Academy of Strategic Management Journal, 2018. 17 (1): p. 1-15.

[23] Nyeko, K. E. and N. K. Sing, Academic Entrepreneurs and Entrepreneurial Academics: Are They the Same. International Journal of Social Science and Humanity, 2015.5 (12): p. 1-6.

[24] Libecap, G., University entrepreneurship and technology transfer: process, design, and intellectual property. Elsevier -The University of Arizona, USA, 2005. 1 (2005): p. 335.

[25] Wright, M., S. Mosey, and H. Noke, Academic entrepreneurship and economic competitiveness: rethinking the role of the entrepreneur. Economics of Innovation and New Technology, 2012. 21 (5-6): p. 429-444.

[26] Wiguna, A. B. and A. Manzilati, Social Entrepreneurship and Socio-entrepreneurship: A Study with Economic and Social Perspective. Procedia - Social and Behavioral Sciences 2014. 115 (2014): p. 12-18

[27] Jones, A. L., B. Warner, and P. Kiser, Social Entrepreneurship. Entrepreneurial Business and Economics Review, 2010. 23 (2010): p. 1-9.

[28] Schieb-Bienfait, N. and C. Urbain, L'entrepreneuriat social, une autre façon d'entreprendre ? Une étude exploratoire sur l'émergence organisationnelle dans l'univers des services à domicile aux personnes âgées. Revue internationale de l'économie sociale, 2004 (293): p. 68-92.

[29] Valéau, P. and J. Boncler, Social entrepreneurship. Revue Interdisciplinaire Management, Homme \& Entreprise », 2013. 2013 (9): p. 46 à 64.

[30] Juma, N. A., C. James, and E. Kwesiga, Sustainable entrepreneurship in Sub-Saharan Africa: the collaborative multi-system model. Journal of Small Business \& Entrepreneurship, 2017. 29 (3): p. 211-235. 
[31] Klein, D. A. and L. Prusak, Characterizing Intellectual Capital. Centre for business innovation, 1994.

[32] Nonaka, I. and H. Takeuchi, The Knowledge-Creating Company: How Japanese Companies Create the Dynamics of Innovation. Oxford, Oxford University Press, 1995.

[33] Bontis, N., Intellectual Capital Disclosure in Canadian Corporations Journal of Human Resource Costing \& Accounting., 2002. 2 (2003): p. 1-16.

[34] Boujelbene, M. A. and H. Affes, Perception du capital intellectuel par les managers: étude empirique dans le contexte tunisien. Comptabilité sans Frontières., 2014. 34 (2014): p. $1-32$.

[35] Chen, J., Z. Zhu, and H. Y. Xie, Measuring intellectual capital: a new model and empirical study. Journal of Intellectual Capital, 2004. 5 (1): p. 195-208.

[36] Meles, A., et al., The impact of the intellectual capital efficiency on commercial banks performance: Evidence from the US. Journal of Multinational Financial Management, 2016. 36 (2016): p. 64-74.

[37] Bouteiller, D., et al., Capital humain et performance(s). Cadres théoriques et protocoles de mesure. HEC Montréal, 2013. 2013 p. 241.

[38] OCDE, L'investissement dans le capital humain: Une comparaison internationale. OCDE, 1998. 1998: p. 121.

[39] Keeley, B., Le capital humain: comment le savoir déterminer ? LES ESSENTIELS DE L'OCDE, 2004 (2004): p. 163.

[40] Yaroson, E. V., N. G. Esew, and A. B. Abdul-Qadir, Human capital development in Nigeria: an empirical assessment on the impact of corruption. African J. Economic and Sustainable Development, 2017. 6 (1): p. 86-103.

[41] Ugalde-BindaI, N., et al., The role of intellectual capital and entrepreneurial characteristics as innovation drivers. Innovar, 2013. 24 (53): p. 41-60.

[42] Rodriguez, J. P. and S. R. Loomis, A new view of institutions, human capital, and market standardisation. Education, Knowledge and Economy, 2007. 1 (1): p. 93-105.

[43] Borges, C. and L. J. Filion, Essaimage universitaire et capital social entrepreneurial. Revue de l'Entrepreneuriat 2016. 15 (2): p. 43 à 73 .

[44] Ordóñez de Pablos, P., Intellectual capital reporting in Spain: a comparative view. Journal of Intellectual Capital, 2003. 4 (1): p. 61-81.

[45] Welbourne, T. and M. Pardo-del-Val, Relational Capital: Strategic Advantage for Small and Medium-Size Enterprises (SMEs) Through Negotiation and Collaboration. Group Decis Negot 2009. 18 (2009): p. 483-497.

[46] Ramírez, Y., M. Manzaneque, and A. M. Priego, La formulation et le développement d'un modèle de mesure du capital intellectuel dans les universités publiques espagnoles. Revue Internationale des Sciences Administratives, 2017. 83 (1): p. 155 à 179 .

[47] Dagenais, C. and M. Janosz, Études des besoins de chercheurs de l'université de Montréal en matière de transfert de connaissances issues de la recherche. Université de Montréal, 2008 (2008): p. 1-96.

[48] Mignon, S. and É. Walliser, Éditorial. Connaissances, capital intellectuel et management de l'innovation. Innovations, 2015. 2 (47): p. pages 5 à 13.

[49] Pépin, M., M. Tremblay, and L. Auderbrand, L'entrepreneuriat responsable: cadre conceptuel et implications pour la formation. Université de Laval, conférence annuelle du Conseil canadien sur les PME et l'entrepreneuriat, mai 2017, 2017. 2017: p. 1-19.

[50] Kalkan, A., Ö. Ç. Bozkurtb, and M. Arman, The impacts of intellectual capital, innovation and organizational strategy on firm performance. Procedia - Social and Behavioral Sciences, 2014. 150 (2014): p. 700-707.

[51] Praag, M. v., Entrepreneurship and Human Capital. Amsterdam Center for Entrepreneurship, 2006 (2006): p. 1-84.

[52] Hashima, M. J., I. Osmanb, and S. M. Alhabshic, Effect of Intellectual Capital on Organizational Performance. Procedia Social and Behavioral Sciences, 2015. 211 (2015): p. 207-214.

[53] Lev, B. and D. Han, The Relationship between Intellectual Capital and Corporate Performance in Chinese Bio-pharmaceutical Industry. SHS Web of Conferences., 2015. 0102 (2015): p. 1-7.

[54] Maboudi, M., et al., The Effect of Intellectual Capital on Innovation: A Case Study of an Institute for Advanced Studies in Basic Sciences Located in the Science and Technology Park of Zanjan.. Journal of Entrepreneurship \& Organization Management, 2015. 4 (148): p. 111-123.

[55] Chandra, Y., Social entrepreneurship as emancipatory work. Journal of Business Venturing, 2017. 32 (2017): p. 657-673.

[56] CNUCED, L'entreprenariat au service de la transformation structurelle: Changer de cap. CNUCED (Nations Unies): RAPPORT 2018 SUR LES PAYSLES MOINS AVANCÉS, 2018 (2018): p. 1-17.

[57] Naneix, C., La promotion de l'entreprenariat vert et de l'éco-innovation sociale au Maroc: État des lieux et recommandations des parties prenantes. switchmed, 2017 (2017): p. 38.

[58] Youssef, A. B. H. and M. Dziri, L'entrepreneuriat vert: mécanismes de mise en oeuvre et motivations en tunisie (cas d'un pays émergent). Vie \& sciences de l'entreprise, 2012. 1992 (191): p. 59 à 77.

[59] Floyd, S. W. and B. Wooldridge, Knowledge creation and social networks in corporate entrepreneurship: The renewal of organizational capability. Entrepreneurship Theory and Practice 1999. 23 (3): p. 123-143.

[60] Zahra, S., A. Nielsen, and W. Bogner, Corporate Entrepreneurship, Knowledge, and Competence Development. Sage Journal, 1999. 23 (3): p. 169-189.

[61] Barney, J., Firm Resources and Sustained Competitive Advantage. Journal of Management, 1991. 17 (1): p. 99-120.

[62] Barney, J., Resource-based theories of competitive advantage: A tenyear retrospective on the resource-based view. Journal of Management 2001. 27 (2001): p. 643-650.

[63] Wernerfelt, B., A resource-based view of the firm. Strategic Management Journal, 1984. 5 (2): p. 171-180.

[64] Bornard, F. and C.-N. Briest-Breda, Développer l'esprit d'entreprendre, une question d'agilité. Revue de l'Entrepreneuriat, 2014. 13 (2): p. pages 29 à 53. 
[65] Legras, S., L'agilité, nouvelle transformation pour l'entreprise. Documentaliste-Sciences de l'Information, 2014.51 (4): p. 4 à 6.

[66] Al-Duaili, M. A. A., Influence of Intellectual Capital in the Organizational Innovation. International Journal of Innovation, Management and Technology, 2012.3 (2): p. 128-135.

[67] Bozeman, B., D. Fay, and C. Slade, Research collaboration in universities and academic entrepreneurship: the-state-of-the-art. J Technol Transf, 2013. 38 (2013): p. 1-67.

[68] Lazega, E. and É. P. Icher, Réseaux sociaux et coopération entre concurrents C. N. R. S. Editions | « Hermès, La Revue », 2011. 1 (59): p. 43 à 49.

[69] Obstfeld, D., Social Networks, the Tertius lungens Orientation, and Involvement in Innovation. Administrative Science Quarterly, 2005. 50 (2005): p. 100-130.

[70] Singh, P. V., Y. Tan, and V. Mookerjee, Network effects: the influence of structural capital on open source project success. MIS Quarterly, 2011. 35 (4): p. pp. 813-829.

[71] Corner, P. D. and S. Wu, Dynamic capability emergence in the venture creation process. International Small Business Journal, 2012. 2012: p. 1-24.

[72] Lichtenthaler, U. and M. Muethel, The Impact of Family Involvement on Dynamic Innovation Capabilities: Evidence From German Manufacturing Firms. ENTREPRENEURSHIP THEORY and PRACTICE, 2012. 2012: p. 1235-1253.

[73] Ramírez, Y., M. Manzaneque, and A. M. Priego, La formulation et le développement d'un modèle de mesure du capital intellectuel dans les universités publiques espagnoles. Revue Internationale des Sciences Administratives 2017. 83 (2017): p. pages 155 à 179.

[74] Châteauneuf-Malclès, A., LE CAPITAL HUMAIN, une source de compétitivité délaissée ? Idées économiques et sociales 2016. 2 (184): p. pages 25 à 34 .

[75] Mengistae, T., Competition and entrepreneurs' human capital in small business longevity and growth Taye Mengistae. The Journal of Development Studies, 2006. 42 (5): p. 812-836.

[76] Vinokur, A., Pourquoi le "capital" humain ? L'Harmattan., 2014 (2014): p. 1-11.

[77] OCDE, Nouvelle source de croissance: le capital intellectuel, analyses de base et conclusion pour l'action gouvernementale. OCDE, 2013. 2013: p. 73.

[78] Bourgault, P., et al., Le devis mixte en sciences infirmières ou quand une question de recherche appelle des stratégies qualitatives et quantitatives. Association de recherche en soins infirmiers, 2010. 4 (103): p. pages 20 à 28 .

[79] Molina-Azorin, J. F., Mixed Methods Research in Strategic Management: Impact and Applications. Organizational Research Methods, 2012. 15 (1): p. pp. 33-56.

[80] Evrard, Y., et al., Market - Fondements et méthodes de recherches en marketing. 2009.

[81] Gogan, L.-M. and A. Draghici, A model to evaluate the intellectual capital. Procedia Technology 2013. 9 (2013): p. 867-875.

[82] Cappelletti, L., Vers un modèle socio-économique de mesure du capital humain? Revue française de gestion, 2010. 8 (207): p. 139 à 152 .

[83] Moon, Y. J. and H. G. Kym, A model for value of intellectuel capital. Revue canadienne de science de l'administration, 2006. 23 (3): p. 253-269.

[84] Guerrero, M., et al., Entrepreneurial universities: emerging models in the new social and economic landscape. Small Bus Econ, 2016. 47 (2016): p. 551-563.

[85] PAUL, B., Université et entrepreneuriat en Haïti MPRA, 2012. 2012 (39015): p. 1-11.

[86] Igalens, J. and P. Roussel, Méthodes de recherche en gestion des ressources humaines. Economica, 1998. 1998: p. 207p.

[87] Armstrong, S. and T. Overton, Estimating nonresponse bias in mail surveys. Journal of Marketing Research, 1977. 14: p. 396-402.

[88] Becker, G. S., Human capital: A theoretical and empirical analysis, with special reference to education University of Chicago Press., 2009.

[89] Crook, T. R., et al., Does human capital matter? A meta-analysis of the relationship between human capital and firm performance. Journal Application Psychologic, 2011. 96 (3): p. 443-56.

[90] Essayie, F. and B. Buclet, Programme sur l'Innovation, l'Enseignement Supérieur et Recherche pour le Développement (IHERD): 8-9 octobre 2013, Dakar, Sénégal. OCDE, 2013. 2013: p. 1-51.

[91] Alain, M., Les us et abus dans l'application de la régression multiple en sciences humaines. Les éditions SMG, 2004. 2004: p. 110 p. 